\title{
Cladocerans from gut contents of fishes associated to macrophytes from Taquari River Basin, MS, Brazil
}

Cladóceros do conteúdo estomacal de peixes associados a macrófitas da Bacia do Rio Taquari, MS, Brasil

Adriana Maria Güntzel ${ }^{1}$, Ilze Katsue Morita Melo ${ }^{1}$, Kennedy Francis Roche², Valéria Flávia Batista da Silva ${ }^{3}$ and Priscila Gusmão Pompiani ${ }^{1}$

${ }^{1}$ Unidade Universitária de Coxim, Universidade Estadual de Mato Grosso do Sul - UEMS, Rua General Mendes de Moraes, 370, Jardim Aeroporto, CEP 79400-000, Coxim, MS, Brazil e-mail: amguntzel@uems.br; ilzekatsue@yahoo.com.br; priscila@uems.br

${ }^{2}$ Universidade Federal de Mato Grosso do Sul - UFMS,

Cidade Universitaria, CEP 79070-900, Campo Grande, MS, Brazil e-mail: kennedy.roche@ufms.br

${ }^{3}$ Unidade Universitária de Mundo Novo, Universidade Estadual de Mato Grosso do Sul - UEMS, BR 163, Km 20,2, CEP 79980-000, Coxim, MS, Brazil e-mail:vfb_silva@uems.br

\begin{abstract}
Aim: The aim of this study was to identify the cladocerans species from the gut contents of fishes sampled in an oxbow lake from Taquari River Basin, MS, with the specific view of investigating the importance of these crustaceans in the fishes diets; Methods: Sampling was carried out in April and August of 2005 (dry season) and January of 2006 (wet season). The fish were captured with a sieve. In the laboratory, individuals were identified and stomachs were removed and weighed. The stomach contents were identified, and a Feeding Index calculated; Results: The items most consumed by fishes were filamentous algae, Cladocera and detritus. The Cladocera were especially important in the August and January samples, and consisted primarily of Chydoridae; cladocerans were most consumed by species of Serrapinnus and by Mesonauta festivus. Fish fed more in April, with decreases occurring in stomach fullness on the other two sampling dates. Conclusions: Cladocerans associated with macrophytes may be an important food source for small fish individuals in marginal lakes from Taquari River Basin. The relative importance of the Chydoridae in the guts may have been due to the high relative abundance and species richness of this group in the environment. A short discussion on fish feeding habits was included in the text.
\end{abstract}

Keywords: microcrustaceans, Chydoridae, ichthyofauna, floodplain, fish feeding.

Resumo: Objetivo: Este estudo teve por objetivo identificar as espécies de cladóceros presentes no conteúdo estomacal de peixes amostrados em uma lagoa marginal da Bacia do Rio Taquari, MS, visando avaliar a importância destes crustáceos na dieta dos peixes; Métodos: A amostragem foi realizada em abril e agosto de 2005 (estaçáo seca) e janeiro de 2006 (estação chuvosa). Os peixes foram capturados com um peneirão. Em laboratório, os indivíduos foram identificados até o nível de espécie e os estômagos removidos e pesados. O conteúdo estomacal foi identificado e um Índice Alimentar calculado. Resultados: Os itens mais consumidos pelos peixes foram algas filamentosas, Cladocera e detritos. Os Cladocera foram especialmente importantes em agosto e janeiro e consistiram principalmente de espécies de Chydoridae; os cladóceros foram mais consumidos por espécies de peixes do gênero Serrapinnus e por Mesonauta festivus. Conclusóes: Cladóceros associados a macrófitas podem ser uma importante fonte de alimento para peixes de pequeno porte em lagoas marginais da Bacia do Rio Taquari. A importância relativa de Chydoridae nos estômagos deve ter sido devida à elevada abundância relativa e riqueza de espécies deste grupo de cladóceros no ambiente. Uma pequena discussão sobre os hábitos alimentares das espécies de peixes encontradas na lagoa foi incluída no texto.

Palavras-chave: microcrustáceos, Chydoridae, ictiofauna, planície de inundação, alimentação de peixes. 


\section{Introduction}

Marginal lakes of floodplain rivers are shallow environments, generally with extensive macrophyte communities that provide a great variety of habitats, representing a rich source of food and protection from predators for the associated invertebrates and fish (Fernando, 1994; Agostinho et al., 2003).

Cladocerans are important components of the invertebrate communities of aquatic macrophytes, presenting elevated richness and abundance (Wisniewski et al., 2000; Güntzel et al., 2010), being an important source of food for various vertebrates and invertebrates (De Bernardi et al., 1987).

According Elmoor-Loureiro and Soares (2010), this group of microcrustaceans was found in the gut content of several Brazilian fishes. The preference of fish for Cladocera has been attributed to their body form and size, conspicuous swimming motion, and less efficient escape response, as compared to the Copepoda (Maia-Barbosa and Matsumura-Tundisi, 1984). Twombly and Lewis Junior (1989) provided evidence that cladocerans (at least the planktonic taxa) in floodplain lakes can suffer high degrees of fish predation.

The objective of the present study was to analyze the trophic relationships between small fish individuals and cladocerans associated with macrophytes of a marginal floodplain lake, with the aim of determining the importance of this group of microcrustaceans in the fish diets.

\section{Study Area}

The Taquari River is one of the main tributaries of the Pantanal (Galdino and Vieira, 2005). The Taquari basin occupies an area of $65,023 \mathrm{~km}^{2}$, and is characterized by a climate of the Aw type, according to the classification system of Köeppen, corresponding to semi-humid tropical, with a mean annual temperature of $26^{\circ} \mathrm{C}$ and mean annual rainfall of between 800 and 1600 mm.year ${ }^{-1}$. Two distinct seasons occur, wet between October and March, and dry between April and September.

Lake Buritizinho ( $18^{\circ} 25^{\prime} 38^{\prime \prime} \mathrm{S}$ and $54^{\circ} 49^{\prime} 44^{\prime \prime}$ W, altitude $194 \mathrm{~m}$ ) is small and shallow, connected to the Taquari River by a narrow channel, and fed by a small stream (Figure 1). The margins and bottom are colonized by a variety of plants, predominantly Mayaca sp., Pontederia sp. and Eichhornia azurea.

\section{Material and Methods}

The collections were carried out in April and August of 2005 and January of 2006, within banks of macrophytes. To capture the fish, a square sieve with an area of $1 \mathrm{~m}^{2}$ and mesh size of $0.5 \mathrm{~mm}$ was used. On each date, an average of 25 sweeps with the sieve was carried out on the left and right margins of the lake. The fish were fixed with $4 \%$ formaldehyde.

The day after collection, the fish were transferred to $70 \%$ ethanol. Individuals were identified to species using Britski et al. (1999). Stomachs (the gut anterior to the pyloric caecae) were removed, weighed and stored in 4\% formaldehyde. Repletion Index (RI) values were calculated according to Santos (1978).

Each stomach was placed in a Petri dish, opened, and its contents observed microscopically. Each food item was identified but the cladocerans until to the lowest taxonomic level possible, and Frequency of Occurrence and Volume determined (Hyslop, 1980; Hellawell and Abel, 1971). The Feeding Index (FI) of Kawakami and Vazzoler (1980) was calculated for each food type.

\section{Results}

A total of 131 small-sized fish specimens (total body lengths of 0.9-5.4 cm) were collected. Two orders (Characiformes and Perciformes), were represented, comprising three fishes families (Characidae, Lebiasinidae and Cichlidae) (Table 1).

Food was found in 45, 24 and 27 guts, in April, August and January, respectively. The greatest degrees of fullness occurred in April, as indicated by the Repletion Index values (April: 0.0241; August: 0.0087 and January: 0.0099).

Cladocerans were encountered in the fish guts in all collection periods, being the second most important item in August and January (Figure 2). The most abundant cladocerans in the guts belonged to the Chydoridae (Table 2).

In April, the most important food items were filamentous algae, followed by insect remains and Ostracoda (Figure 2). In August, the fish mostly consumed filamentous algae, Cladocera, detritus and insect remains. In January, highest consumption was for filamentous algae, Cladocera and detritus.

\section{Discussion}

The second most important item in the fish guts was the cladocerans, especially on the sampling dates when the Serrapinnus species was most abundant. Many studies have recorded this group as being an important food item for fish (Luz et al., 2001; Meschiatti and Arcifa, 2002; Carvalho et al., 2003; Roche and Rocha, 2005a, and references therein). 


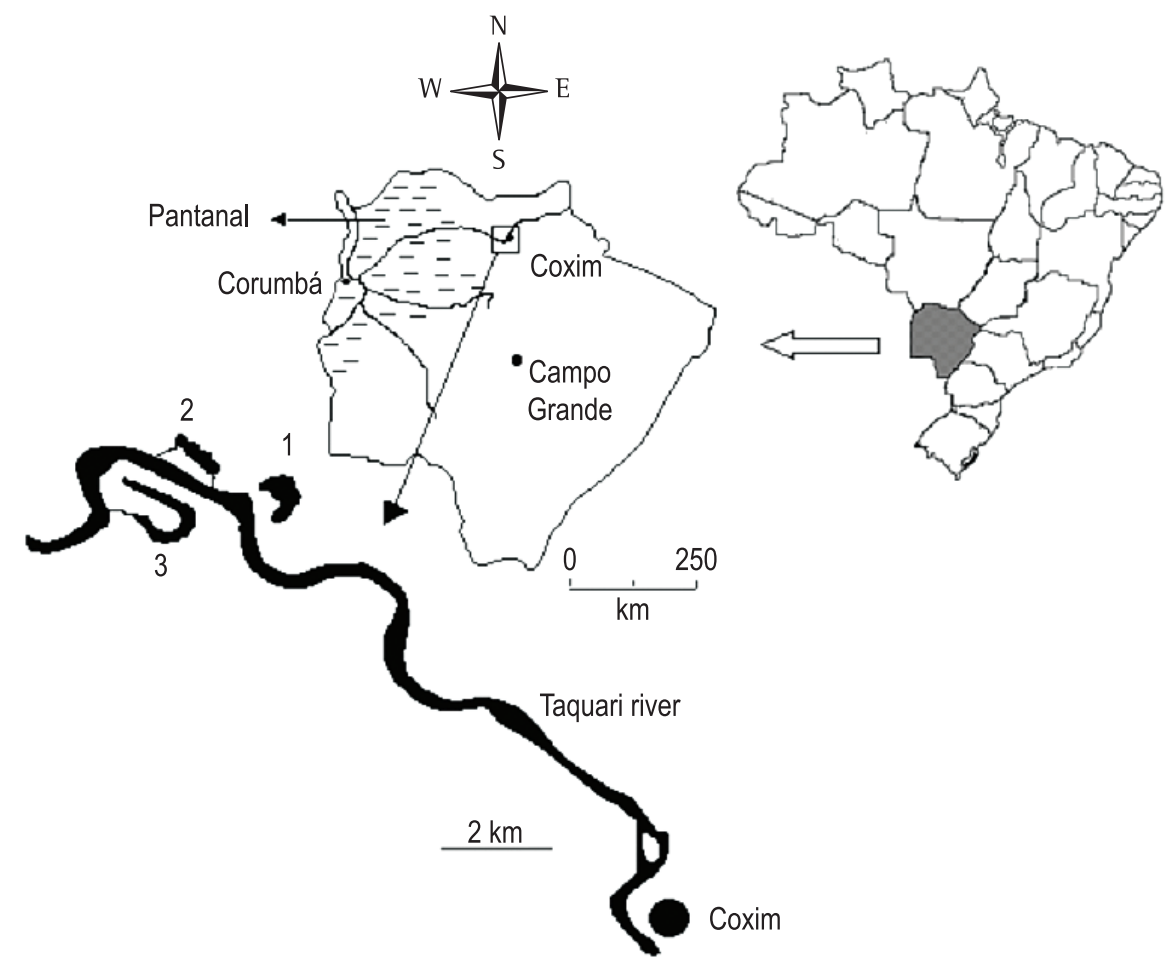

Figure 1. Study area in the Middle Taquari River Basin: Lake Buritizinho is indicated by the number 1 .

Table 1. Species of cladocerans identified in the stomachs of the fish species.

H. eques Serrapinnussp. Pyrrhulina sp. A. trifasciata M. festivus

\section{Family Chydoridae}

Acroperus harpae

Alona cf. poppei

Alona ossiani

Alonella brasiliensis

Alonella cf. clathratula

Alonella dadayi

Camptocercus australis

Chydorus sp.

Chydorus eurynotus

Chydorus pubescens

Chydorus sphaericus

Disparalona leptorhyncha

Ephemeroporus barroisi

Ephemeroporus hybridus

Ephemeroporus tridentatus

Euryalona orientalis

Leydigiopsis $\mathrm{sp}$.

Leydigiopsis curvirostris

Notoalona sculpta

Unidentified

Family Macrothricidae

Macrothrix paulensis

Macrothrix spp.

\section{Family Sididae}

Diaphanosoma sp.

Pseudosida ramosa

\section{Family Daphniidae}

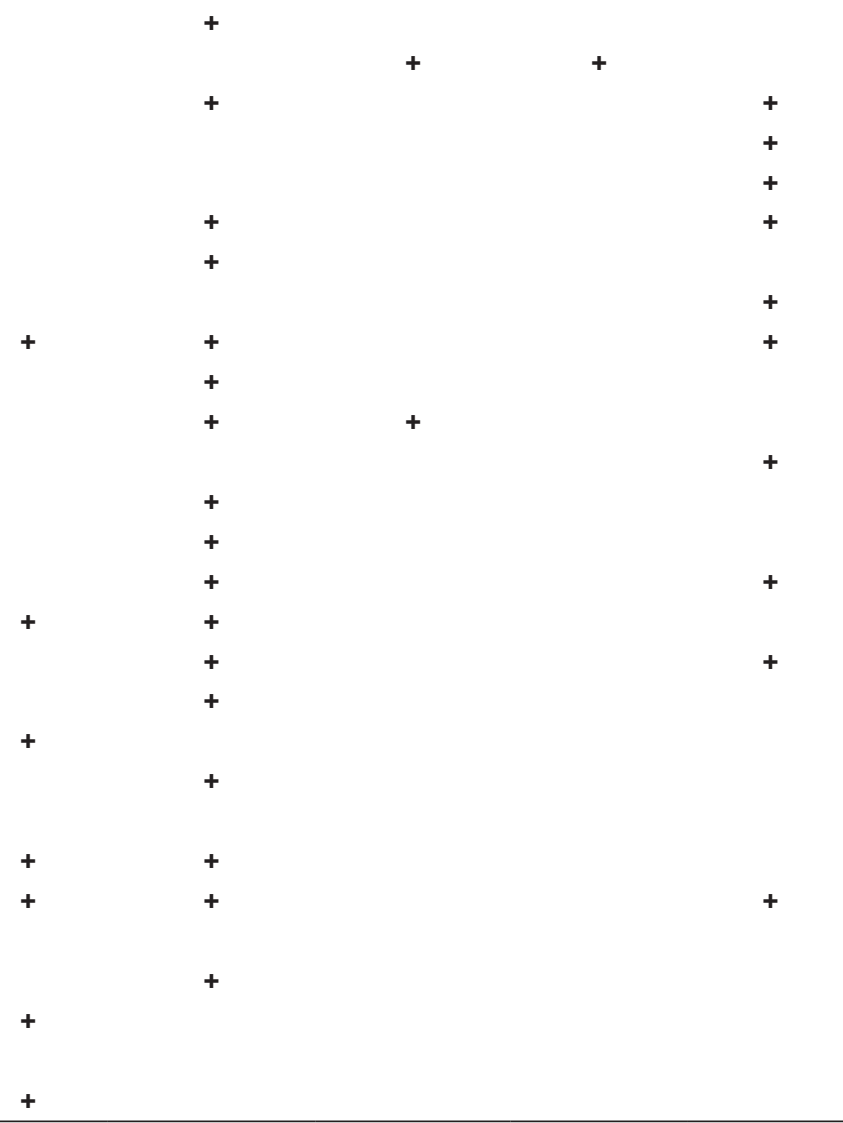


Table 2. Numbers of fish individuals captured in the macrophyte banks.

\begin{tabular}{lccc}
\hline & April '05 & August '05 & January '06 \\
\hline $\begin{array}{l}\text { Order Characiformes } \\
\text { Family Characidae }\end{array}$ & & & \\
$\quad$ Moenkhausia sanctaefilomenae & 4 & 1 & - \\
Hyphessobrycon eques & 22 & - & 7 \\
$\quad$ Astyanax sp. & 1 & 26 & 23 \\
$\quad$ Serrapinnus sp. & 2 & - & 1 \\
Family Lebiasinidae & & & 2 \\
$\quad$ Pyrrhulina australis & 3 & 2 & 4 \\
Order Perciformes & & 2 & 3 \\
Family Cichlidae & 11 & 3 & \\
Apistogramma trifasciata & 7 & & \\
Laetacara dorsigera & - & & \\
Mesonauta festivus & & & \\
\hline
\end{tabular}
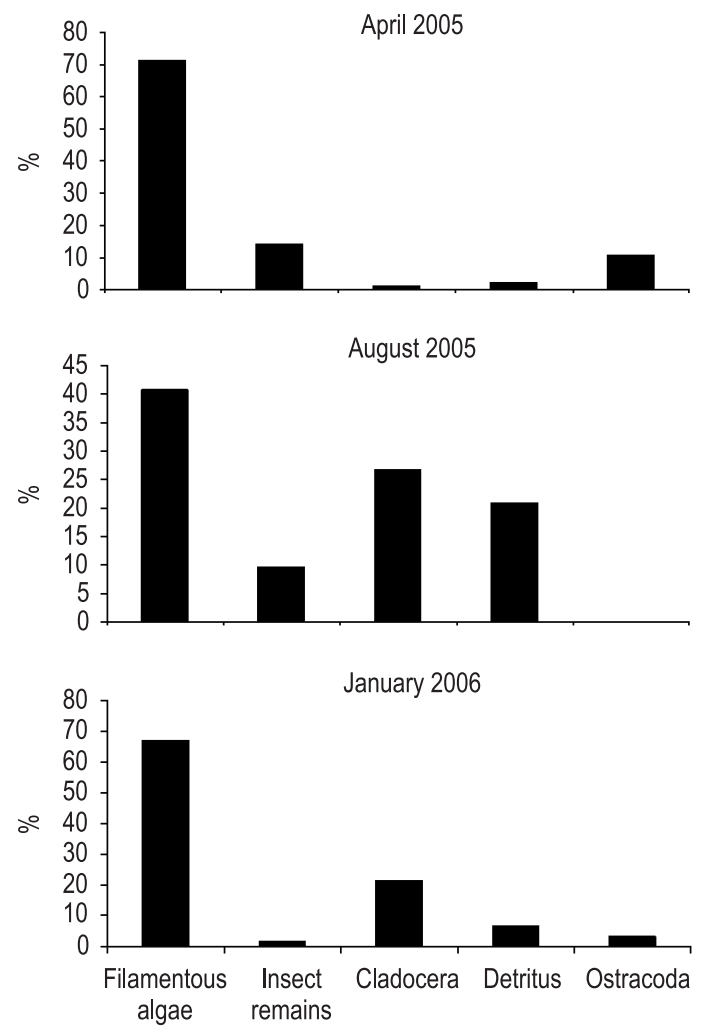

Figure 2. Feeding Index (\%) results for the collection dates.

The great abundance of Cladocera associated with macrophytes could explain the importance of these organisms for the fish feeding in the present study (Lansac-Tôha et al., 2003; Güntzel et al., 2010). A similar conclusion was formed by Alvim et al. (1998) for Holoshesthes heterodon feeding in macrophyte banks of a reservoir.

For the three sampling periods of the present study, cladoceran abundance was highest in August, with Chydorus eurynotus the most numerous species (Güntzel et al., 2010). The cladoceran communites were found to consist principally of Chydoridae and Macrothricidae, followed by Ilyocryptidae during the fish sampling periods.

Planktonic taxa, such as Diaphanosoma and Ceriodaphnia were recorded sporadically in this lake, at very low densities, especially during the fish sampling periods. The importance of Chydoridae in the guts is a consequence of their elevated abundance and species richness in the environment.

Our findings support the conclusion reached by Meschiatti et al. (2000) and Meschiatti and Arcifa (2002) that non-planktonic microcrustaceans, especially Chydoridae, can be more important than planktonic forms as food items in marginal lakes.

In the present study, the majority of fish encountered were small characins and cichlids, as is typical for neotropical macrophyte banks (Meschiatti and Arcifa, 2002; Casatti et al., 2003; Roche et al., 2005b and references therein). It is important to emphasize that specimens identified as the genus Cheirodon in Pantanal samples are now considered as Serrapinnus (Britski et al., 2007).

In January, during the breeding season of the fish, that goes from November to February (Vazzoler, 1996), the greatest proportion of empty stomachs was observed, corroborating the findings of Gurgel et al. (1994), where minimum values of stomach fullness were recorded in the period after spawning for both sexes of the fish species studied.

When interpreting the analysis of fish gut contents, it must be borne in mind that the abundance of an item does not necessarily imply that that item is an important food source. Thus, some items, such as seeds and zooplankton eggs, may not be successfully digested, and may accumulate in the gut, while especially soft-bodied prey items, prone to rapid digestion, may be 
underestimated in gut contents (Zavala-Camin, 1996; Coutinho et al., 2000).

Overall, the Cladocera, principally non-planktonic forms, were an important component of the fish diets, suggesting that these organisms are an important part of the lake's food web, especially with regard to small fish individuals. Further studies are planned, with greater sampling effort, to compare interspecific differences in diets, feeding rates and patterns of selectivity in this lake, and to compare such results with other marginal lakes in the area.

\section{Acknowledgements}

This study was financed by FUNDECT Foundation for the Support of the Development of Teaching, Science and Technology of the State of Mato Grosso do Sul, and CNPq - National Council of Scientific and Technological Development.

\section{References}

AGOSTINHO, AA., HAHN, NS. and MARQUES, EE. 2003. Patterns of food resources use by two congeneric species of piranhas (Serrasalmus) on the upper Parana River floodplain. Brazilian Journal of Biology, vol. 63, no. 2, p. 177-182. PMid:14509839.

ALVIM, MCC., MAIA-BARBOSA, PM. and ALVES, CBM. 1998. Feeding of Holoshesthes heterodon Eigenmann (Teleostei, Cheirodontine) of the Cajuru reservoir (Minas Gerais, Brazil), in relation to the vegetal biomass on its depletion zone. Revista Brasileira de Zoologia, vol. 15. no. 4, p. 995-1002. http://dx.doi. org/10.1590/S0101-81751998000400018

BRITSKI, HA., SILIMON, KZS. and LOPES, BS. 1999. Peixes do Pantanal: Manual de identificaçấo. Brasília: EMBRAPA-SPI. $184 \mathrm{p}$.

BRITSKI, HA., SILIMON, KZS. and LOPES, BS. 2007. Peixes do Pantanal: Manual de identificação. Brasília: EMBRAPA-SPI. 230 p.

CARVALHO, ED., DE CASTRO, RJ., DA SILVA, VFB. and VIDOTTO, AP. 2003. A estrutura das assembléias de peixes nas zonas de ecótono da Represa de Jurumirim (alto do rio Paranapanema, SP). In HENRY, R., org. Ecótonos nas interfaces dos ecossistemas aquáticos. FUNDIBIO: RIMA.

CASATTI, L., MENDES, HF. and FERREIRA, KM. 2003. Aquatic macrophytes as feeding site for small fishes in the Rosana Reservoir, Paranapanema River, southeastern Brazil. Brazilian Journal of Biology, vol. 63, no. 2, p. 213-222. http://dx.doi. org/10.1590/S1519-69842003000200006

COUTINHO, AB., AGUIARO, T., BRANCO, CWC., ALBUQUERQUE, EF. and SOUZA FILHO, IF. 2000. Alimentaçáo de Hyphessobrycon bifasciatus Ellis, 1911 (Osteichthyes, Characidae) na Lagoa
Cabiúnas, Macaé, RJ. Acta Limnologica Brasiliensia, vol. 12, p. 45-54.

DE BERNARDI, R., GIUSSANI, G. and MANCA, M. 1987. Cladocera: Predators and Prey. Hydrobiologia, vol. 145, p. 225-243. http://dx.doi. org/10.1007/BF02530284

ELMOOR-LOUREIRO, LMA. and SOARES, CEA. 2010. Cladocerans from gut contents of fishes from Guaporé River Basin, MT, Brazil. Acta Limnologica Brasiliensia, vol. 22, no. 1, p. 46-49. http://dx.doi.org/10.4322/actalb.02201006

FERNANDO, CH. 1994. Zooplankton, fish and fisheries in tropical freshwaters. Hydrobiologia, vol. 272, p. 105-123. http://dx.doi.org/10.1007/ BF00006516

GALDINO, S. and VIEIRA, LM. 2005. A Bacia do Rio Taquari e seus problemas ambientais e sócioeconômicos. In GALDINO, S., VIEIRA, ML. and PELLEGRIN, AL., orgs. Impactos ambientais e sócio-econômicos na Bacia do Rio Taquari - Pantanal. Corumbá: Embrapa Pantanal.

GÜNTZEL, AM., PANARELLI, EA., DA SILVA, WM. and ROCHE, KF. 2010. Influence of connectivity on Cladocera diversity in oxbow lakes in the Taquari River floodplain (MS, Brazil). Acta Limnologica Brasiliensia, vol. 22, no. 1, p. 93-101. http://dx.doi. org/10.4322/actalb.02201012

GURGEL, HCB., DE ALMEIDA, RG. and BARBIERI, G. 1994. Análise qualitativa da alimentação e o coeficiente intestinal de Metynnis c.f. roosevelti Eigenmann (Characidae, Myleinae), da Lagoa Redonda, Nízia floresta, Rio Grande do Norte, Brasil. Revista Brasileira de Zoologia, vol. 11, no. 2, p. 331-339. http://dx.doi.org/10.1590/S010181751994000200018

HELLAWELL, JM. and ABEL, R. 1971. A rapid volumetric method for the analysis of the food of fishes. Journal of Fish Biology, vol. 3, p. 29-37. http:// dx.doi.org/10.1111/j.1095-8649.1971.tb05903.x

HYSLOP, EJ. 1980. Stomach contents analysis a review of methods and their application. Journal of Fish Biology, vol. 17, p. 411-429. http://dx.doi. org/10.1111/j.1095-8649.1980.tb02775.x

KAWAKAMI, E. and VAZZOLER, G. 1980. Método gráfico e estimativa de índice alimentar aplicado no estudo de alimentação de peixes. Boletim Instituto Oceanográfico, vol. 29, p. 205-207. http://dx.doi. org/10.1590/S0373-55241980000200043

LANSAC-TÔHA, FA., MACHADO, LF. and BONECKER, CC. 2003. Influência de macrófitas aquáticas sobre a estrutura da comunidade zooplanctônica. In THOMAZ, SM. and BIBI, LM., orgs. Ecologia e manejo de macrófitas aquáticas. Maringá: Eduem.

LUZ, KDG., ABUJANRA, F., AGOSTINHO, AA. and GOMES, LC. 2001. Caracterização trófica da 
ictiofauna de três lagoas da planície aluvial do alto Rio Paraná, Brazil. Revista Unimar, vol. 23, no. 2, p. 401-407.

MAIA-BARBOSA, PM. and MATSUMURA-TUNDISI, TM. 1984. Consumption of zooplanktonic organisms by Astyanax fasciatus Cuvier, 1819 (Osteichthyes, Characidae) in Lobo (Broa) reservoir, São Carlos, SP, Brazil. Hydrobiologia, vol. 113, p. 171-181.

MESCHIATTI, AJ. and ARCIFA, MS. 2002. Early life stages of fish and the relationships with zooplankton in a tropical Brazilian reservoir: Lake Monte Alegre. Brazilian Journal of Biology, vol. 62, no. 1, p. 41-50. http://dx.doi.org/10.1590/S151969842002000100006

MESCHIATTI, AJ., ARCIFA, MS. and FENERICHVERANI, N. 2000. Ecology of fish in oxbow lakes of Mogi-Guaçu River. In SANTOS, JE. DOS and PIRES, JSR., orgs. Estudos Integrados em Ecossistemas: Estação Ecológica de Jataí. São Carlos: RiMa. 867 p. vol. 2.

ROCHE, KF. and ROCHA, O. 2005a. Aspectos de predação por peixes em lagos e represas, com enfoque na planctivoria. In ROCHE, KF. and ROCHA, O., orgs. Ecologia trófica de peixes, com ênfase na planctivoria em ambientes lênticos de água doce no Brasil. São Carlos: RiMa. 136 p.
ROCHE, KF., RIETZLER, AC. and ROCHA, O. 2005b. Dieta de Astyanax bimaculatus, Cheirodon stenodon, Serrasalmus spilopleura, e Plagioscion squamosissimus em duas represas, com ênfase nos indivíduos juvenis. In ROCHE, KF. and ROCHA, O., orgs. Ecologia trófica de peixes, com ênfase na planctivoria em ambientes lênticos de água doce no Brasil. São Carlos: RiMa. 136 p.

SANTOS, EP. 1978. Dinâmica de populaçóes aplicada á pesca e piscicultura. São Paulo: EDUSP. 129 p.

TWOMBLY, S. and LEWIS JUNIOR, WM. 1989. Factors regulating cladoceran dynamics in a Venezuelan floodplain lake. Journal of Plankton Research, vol. 11, no. 2, p. 317-333. http://dx.doi. org/10.1093/plankt/11.2.317

VAZZOLER, AEAM. 1996. Biologia da reprodução de peixes teleósteos: teoria e prática. Maringá: EDUEM.196 p.

WISNIEWSKI, MJS., ROCHA, O., RIETZLER, AC. and ESPÍNDOLA, ELG. 2000. Diversidade do zooplâncton nas lagoas marginais do Rio Mogi-Guaçu: II. Cladocera (Crustacea, Branchiopoda). In SANTOS, JE. and PIRES, JSR., orgs. Estudos Integrados em Ecossistemas: Estação ecológica de Jataí. São Carlos: RiMa. vol. 2, 867 p.

ZAVALA-CAMIN, LA. 1996. Introdução aos estudos sobre alimentação natural em peixes. Maringá: Eduem. 129 p. 